\title{
Tree Species Richness, Diversity, and Vegetation Index for Federal Capital Territory, Abuja, Nigeria
}

\author{
Aladesanmi D Agbelade, ${ }^{1}$ Jonathan C. Onyekwelu, ${ }^{2}$ and Matthew B. Oyun ${ }^{2}$ \\ ${ }^{1}$ Department of Forest Resources and Wildife Management, Faculty of Agricultural Sciences, \\ Ekiti State University, PMB 5363, Ado Ekiti, Ekiti State, Nigeria \\ ${ }^{2}$ Department of Forestry and Wood Technology, School of Agriculture and Agricultural Technology, \\ Federal University of Technology, PMB 704, Akure, Ondo State, Nigeria \\ Correspondence should be addressed to Aladesanmi D Agbelade; aladesanmi2008@gmail.com
}

Received 3 August 2016; Revised 13 November 2016; Accepted 28 November 2016; Published 31 January 2017

Academic Editor: Piermaria Corona

Copyright (C) 2017 Aladesanmi D Agbelade et al. This is an open access article distributed under the Creative Commons Attribution License, which permits unrestricted use, distribution, and reproduction in any medium, provided the original work is properly cited.

This study was conducted to investigate the tree species richness and diversity of urban and periurban areas of the Federal Capital Territory (FCT), Abuja, Nigeria, and produce Normalized Difference Vegetation Index (NDVI) for the territory. Data were collected from urban (Abuja city) and periurban (Lugbe) areas of the FCT using both semistructured questionnaire and inventory of tree species within green areas. In the study location, all trees with diameter at breast height $(\mathrm{dbh}) \geq 10 \mathrm{~cm}$ were identified; their dbh was measured and frequency was taken. The NDVI was calculated in ArcGIS 10.3 environment using standard formula. A cumulative total of twenty-nine (29) families were encountered within the FCT, with 27 occurring in Abuja city (urban centre) and 12 in Lugbe (periurban centre) of the FCT. The results of Shannon-Wiener diversity index $\left(H^{\prime}\right)$ for the two centres are 3.56 and 2.24 while Shannon's maximum diversity index $\left(H_{\max }\right)$ is 6.54 (Abuja city) and 5.36 (Lugbe) for the urban (Abuja city) and periurban (Lugbe) areas of the Federal Capital Territory (FCT). The result of tree species evenness (Shannon's equitability $\left(E_{H}\right)$ index) in urban and periurban centres was 0.54 and 0.42 , respectively. The study provided baseline information on urban and periurban forests in the FCT of Nigeria, which can be used for the development of tree species database of the territory.

\section{Introduction}

Urban forests are made up of the trees, shrubs, and other vegetative covers that play important role in human life. Urban forests serve important roles such as tree species diversity conservation and protection of fragile ecosystem; development of parks and event centres for relaxation and social engagements; provision of vegetable and fruits/seeds for foods and medicines; and purification of air, wind break, and beautification of the environment [1]. Research in developing countries has revealed that trees are planted around houses for fruits, nuts, leaves, fuelwood, fodder, vegetables, shade, and windbreaks [2]. In traditional African settlements, it is usually common to plant trees in village squares to provide shade for social meetings, ceremonies, recreation, and religious worships. The growing urban population in Nigeria is redefining urban forestry practices and has presented new challenges and opportunities for researchers.

Urbanization in developing countries is on the increase and this has resulted in social burden in the urban cities due to their limited capacity to adapt to socioeconomic challenges of the new environments [3]. Global projections indicate that future trends in urbanization could triple between 2000 and 2030 [4-7]. According to 2011 revision of World Urbanization Prospects, the urban areas of the world is expected to gain 1.4 billion people between 2011 and 2030, $37 \%$ of which will come from China (276 million) and India (218 million). The report predicts that between 2030 and 2050 another 1.3 billion people will be added to the global urban population. With a total addition of 121 million people, Nigeria will be the second major contributor next to India (270 million) [8]. The negative effect of urban expansion includes threat to ecosystem biodiversity and carbon emis- 
sions due to tropical deforestation and expansion of social infrastructure [9].

The increasing population of Abuja city, Nigeria's Federal Capital Territory (FCT), has led to a wide range of challenges which has now put lots of pressure on land, forest and forest resources, and green spaces and exposed the city to different environmental hazards. Environmental hazards such as air pollution, wind, and water erosion are on the increase as a result of deforestation and population increase within the FCT and this is evident in different parts of Nigeria cities $[2,10]$. In our growing urbanized environments, the maintenance and development of urban vegetated areas are among the challenges of sustainable urban planning $[2,11]$.

Research has suggested that urban forest and urban green areas could be another effective means of biodiversity conservation and ecosystems potentials in terms of physiological, sociological, economic, and aesthetic benefits [12]. Urban forests could also be used to reduce the challenges posed by urbanization such as food insecurity, energy shortage, deteriorating air quality, high temperatures, health hazards, and increased noise levels [2]. Other benefits derived from urban forests include healthy environment which translates to healthy citizens, beautification of the environment and scenery, cooler air temperature, reductions in ultraviolet radiation, and social and ecological benefits $[9,11,13]$. This study investigates tree species richness, diversity, and vegetation index for Federal Capital Territory, Abuja, Nigeria.

\section{Methodology}

2.1. Location of Study Area. The study was conducted in Abuja, the Federal Capital Territory (FCT) of Nigeria. The city lies between latitude and $9^{\circ} 03^{\prime}$ and $9^{\circ} 07^{\prime} \mathrm{N}$ and longitude $7^{\circ} 26^{\prime}$ and $7^{\circ} 39^{\prime} \mathrm{E}$ in the North central region of Nigeria. Abuja experiences tropical wet and dry climate. The FCT experiences a warm, humid rainy season and a blistering dry season (harmattan), occasioned by the northeast trade wind, with the main features of dust haze, intensified coldness, and dryness. Rainfall in the FCT reflects the territory's location on the windward side of the Jos Plateau and the zone of rising air masses. Balogun [14] opined that, due to the hilly and mountainous nature of Abuja city, orographic activities bring heavy and frequent rainfall during the rainy season. The rainy season begins in March and ends in November, with peak in September, during which abundant rainfall is received. Mean annual rainfall in Abuja ranges from $1000 \mathrm{~mm}$ to $1600 \mathrm{~mm}$. Mean monthly temperature ranges between $25.8^{\circ} \mathrm{C}$ and $30.2^{\circ} \mathrm{C}[14,15]$. The soils of the study area are basically Alluvial and Luvisols, which supports growth of tree species such as Khaya spp., Parkia biglobosa, Delonix regia, Eucalyptus spp., Azadirachta indica, and Gmelina arborea [16].

Lugbe is one of the popular suburban settlements in Abuja. It is in the Abuja Municipal Area Council (AMAC). It is largely residential and densely populated. Lugbe is about 17 minutes' drive from the Central Business District of Abuja and 13 minutes' drive to the Abuja Airport. Though Lugbe is not in the Federal Capital City (FCC), its proximity to the city centre and also to the Abuja Airport has brought it into lime light and attracted significant development to the area. The area is developing very fast and it houses the National Space Development and Research Agency, Federal Housing Authority (FHA) Estate, and Voice of Nigeria Transmission Station.

\section{Data Collection}

The city of Abuja was purposefully selected as the urban sector for this research based on its high infrastructural development, population density, and its economic importance in Nigeria while the closest satellite town (Lugbe) was selected as the periurban settlement. Both semistructured questionnaire and biodiversity assessment were used for data collection. The questionnaire was used to obtain information on the socioeconomic and environmental benefits of urban forest. Twenty respondents were purposefully selected in each urban and periurban centre of the FCT, which translated to a total of forty (40) questionnaires for this study. Administration of questionnaires was done using snowball sampling; respondents were those who own tree(s) or who have association(s) with tree(s). This was supported by earlier study by [11] which used snowball sampling methods due to the peculiarity of urban forest development in Ibadan metropolis. These questionnaires were administered in form of interview guide, such that respondents were requested to complete and return them immediately, thus resulting in 100\% retrieval. The study covers $20 \%$ of Abuja Federal Capital Territory (FCT) built-up centres. The biodiversity assessment entails complete enumeration of tree species in public parks/garden, private gardens/home gardens, avenue/roadside trees, school grounds, public and private institutions, and any space with conglomerates of trees. Within the selected urban and periurban centre, all trees with diameter at breast height $(\mathrm{dbh}) \geq 10 \mathrm{~cm}$ were identified; their diameters at breast height, diameters at the base, middle, and top, and total height were measured while their frequencies were taken. All tree species in each city were assigned to families using Keay [17] as guide.

\section{Data Processing and Analysis}

4.1. Computation of Normalized Difference Vegetation Index (NDVI). Normalized Difference Vegetation Index (NDVI) is one of the most widely used vegetation indices, which is applicable in satellite analysis and monitoring of vegetation cover $[18,19]$. In this study, the NDVI was calculated in ArcGIS 10.3 environment using

$$
\mathrm{NDVI}=\frac{\mathrm{NIR}-\mathrm{VIS}}{\mathrm{NIR}+\mathrm{VIS}}
$$

where NDVI is Normalized Difference Vegetation Index, NIR is near infrared, and VIS is visible red reflectance.

The value of the pixels varies between -1 and +1 ; the higher the value of NDVI, the richer and healthier the vegetation cover of such environment.

4.2. Computation of Growth Parameters and Biodiversity Indices. The computations of the following growth parameter and biodiversity indices were undertaken. 
4.2.1. Basal Area. The basal area of all trees in this study area was calculated using

$$
\mathrm{BA}=\frac{\pi D^{2}}{4}
$$

where BA is basal area $\left(\mathrm{m}^{2}\right), D$ is diameter at breast height $(\mathrm{cm})$, and $\pi$ is pie (3.142). The total BA for the city was obtained by adding all trees BA in the city.

4.2.2. Volume. Volume of individual trees was estimated using tree volume equation developed Newton's formula as follows [20]:

$$
V=\pi h \frac{D b^{2}+4\left(D m^{2}\right)+D t^{2}}{24},
$$

where $V$ is tree volume $\left(\mathrm{m}^{3}\right), D b, D m$, and $D t$ are diameters (m) at the base, middle, and top of each tree, and $h$ is total tree height $(\mathrm{m})$.

4.2.3. Species Relative Density (RD). Species relative density, which is an index for assessing species relative distribution [21], was computed with

$$
\mathrm{RD}=\left(\frac{n_{i}}{N}\right) \times 100
$$

where $\mathrm{RD}(\%)$ is species relative density; $n_{i}$ is the number of individuals of species $i$; and $N$ is the total number of all individual trees of all species in the entire community.

4.2.4. Species Relative Dominance $\left(\mathrm{RD}_{o}\right)$. Species Relative Dominance $\left(\mathrm{RD}_{o}(\%)\right)$, used in assessing relative space occupancy of a tree, was estimated using [22]

$$
\mathrm{RD}_{o}=\frac{\left(\sum \mathrm{Ba}_{i} \times 100\right)}{\sum \mathrm{Ba}_{n}}
$$

where $\mathrm{Ba}_{i}$ is basal area of all trees belonging to a particular species $i$ and $\mathrm{Ba}_{n}$ is basal area of all trees in a city.

4.2.5. Importance Value Index (IVI). The Importance Value Index (IVI) of each species was computed with the relationship in the following equation [21]:

$$
\mathrm{IVI}=\frac{\left(\mathrm{RD}+\mathrm{RD}_{o}\right)}{2}
$$

4.2.6. Species Diversity Index. Species diversity index $\left(H^{\prime}\right)$ was computed using the Shannon-Wiener diversity index in the following equation $[23,24]$ :

$$
H^{\prime}=-\sum_{i=1}^{s} P_{i} \ln \left(P_{i}\right)
$$

where $H^{\prime}$ is Shannon-Wiener diversity index; $s$ is the total number of species in the community; $P_{i}$ is the proportion of $S$ made up of the $i$ th species; and $\ln$ is natural logarithm.
4.2.7. Shannon's Maximum Diversity Index. Shannon's maximum diversity index was calculated using [24]

$$
H_{\max }=\ln (S) \text {, }
$$

where $H_{\max }$ is Shannon's maximum diversity index and $S$ is the total number of species in the community.

4.2.8. Species Evenness. Species evenness in each city was determined using Shannon's equitability $\left(E_{H}\right)$, which was obtained using [23]

$$
E_{H}=\frac{H^{\prime}}{H_{\max }}=\frac{-\sum_{i=1}^{s} P_{i} \ln \left(P_{i}\right)}{\ln (S)} .
$$

4.2.9. Sorensen's Species Similarity Index. Sorensen's species similarity index between two cities was calculated using [25, 26]

$$
\mathrm{SI}=\left(\frac{2 C}{a+b}\right) \times 100,
$$

where $C$ is the number of species in sites $a$ and $b$ and $a$ and $b$ $=$ number of species at sites 1 and 2 , respectively.

4.3. Data Analyses. After retrieval, the questionnaires were coded to obtain quantitative values for statistical analysis. Descriptive analysis was used to summarise the data while correlation analysis was used to investigate the relationships between some biodiversity indices and growth variables. Student's $t$-test was used to test for significant difference in the growth variables of individual trees in urban and periurban areas for the study. All statistical analyses were undertaken using Statistical Package for Social Sciences (SPSS 20.0) software package. Normalized Difference Vegetation Index of the entire city was calculated and analysed in ArcGIS 10.3 environment to determine the level of greenness of the city between 2000 and 2015 .

\section{Results}

5.1. Biodiversity Indices and Growth Variables. A cumulative total of twenty-nine (29) families were encountered within the FCT, with 27 occurring in Abuja city (i.e., urban centre) and 12 in Lugbe (i.e., periurban centre) of the FCT (Table 1). Within the urban and periurban areas, families with high number of tree species include Fabaceae, Moraceae, Euphorbiaceae, Combretaceae, Arecaceae, and Myrtaceae. A pooled total of 69 in Abuja city and 20 in Lugbe were identified within the FCT. Numbers of tree species were higher in the urban centre (Abuja city) than in the periurban area (Lugbe) (Table 1). The results of Student's $t$-test showed that both number of family and tree species were significantly higher in the urban area than the periurban area of the FCT. Based on the results of tree growth parameters, the trees in the urban area were larger than those in the periurban area. Results in Table 1 show that mean dbh $(59.3 \mathrm{~cm})$, basal area $\left(51.03 \mathrm{~m}^{2}\right)$, volume $\left(752.8 \mathrm{~m}^{3}\right)$, and maximum $\mathrm{dbh}(212.3 \mathrm{~cm})$ of tree in Abuja city (urban area) were significantly higher than the values recorded for the corresponding parameters 
TABLE 1: Summary result of biodiversity indices and growth parameters for tree species in urban and periurban areas of FCT.

\begin{tabular}{lcc}
\hline \multirow{2}{*}{ Benefits derived } & \multicolumn{2}{c}{ Federal Capital Territory (FCT) } \\
& Urban forest & Periurban forest \\
\hline Number of individual trees & $695^{\mathrm{a}}$ & $213^{\mathrm{b}}$ \\
Number of species & $69^{\mathrm{a}}$ & $20^{\mathrm{b}}$ \\
Number of families & $27^{\mathrm{a}}$ & $12^{\mathrm{b}}$ \\
Mean Dbh $(\mathrm{cm})$ & $59.3^{\mathrm{a}}$ & $16.2^{\mathrm{b}}$ \\
Basal area $\left(\mathrm{m}^{2}\right)$ & $51.03^{\mathrm{a}}$ & $13.70^{\mathrm{b}}$ \\
Maximum Dbh $(\mathrm{cm})$ & $212.3^{\mathrm{a}}$ & $190.7^{\mathrm{b}}$ \\
Volume $\left(\mathrm{m}^{3}\right)$ & $752.8^{\mathrm{a}}$ & $191^{\mathrm{b}}$ \\
Diversity index $\left(H^{\prime}\right)$ & $3.56^{\mathrm{a}}$ & $2.24^{\mathrm{b}}$ \\
Max diversity $\left(H_{\max }\right)$ & $6.54^{\mathrm{a}}$ & $5.36^{\mathrm{b}}$ \\
Species evenness $\left(E_{H}\right)$ & $0.54^{\mathrm{a}}$ & $0.42^{\mathrm{a}}$ \\
\hline
\end{tabular}

Values followed by similar letters are not significantly different $(p>0.05)$.

in Lugbe (periurban area). Also, the frequency of occurrence of individual trees in urban area of Abuja was significantly higher than that of the periurban centre of the city.

The results of Shannon-Wiener diversity index $\left(H^{\prime}\right)$ for the two centres are 3.56 and 2.24 while Shannon's maximum diversity index $\left(H_{\max }\right)$ is 6.54 (Abuja city) and 5.36 (Lugbe) for the urban (Abuja city) and periurban (Lugbe) areas of the Federal Capital Territory (FCT). The result of tree species evenness (Shannon's equitability $\left(E_{H}\right)$ index) in urban and periurban centres was 0.54 and 0.42 , respectively.

The result also revealed that the species relative density (RD) for individual trees in the urban and periurban centres of the FCT ranged from 0.14 to $10.41 \%$ in Abuja city and from 0.47 to $33.80 \%$ Lugbe (Tables 2 and 3). Tree species with high relative density (RD) in Lugbe were Gmelina arborea, Parkia biglobosa, and Mangifera indica, accounting for $33.80 \%, 12.21 \%$, and $9.39 \%$, respectively, while in Abuja city Gmelina arborea (10.40\%), Terminalia ivorensis (6.07\%), and Delonix regia (5.35\%) had high relative density. Species Relative Dominance $\left(\mathrm{RD}_{o}\right)$ varied from 0.04 to $6.94 \%$ in Abuja city and from 0.15 to $20.85 \%$ in Lugbe. Within the urban areas (Abuja city), tree species with high Relative Dominance $\left(\mathrm{RD}_{o}\right)$ were Spathodea campanulata $(6.94 \%)$, Nauclea latifolia (5.68\%), and Azadirachta indica (5.60\%) while, in the periurban areas (Lugbe) of the FCT, Azadirachta indica (20.85\%), Ricinodendron heudelotii (16.77\%), and Nauclea diderrichii (10.59\%) dominated. Tree species with high Importance Value Index were Gmelina arborea (5.82\%), Azadirachta indica (3.96\%), and Khaya senegalensis (3.74\%) in Abuja city while Azadirachta indica (14.18\%), Parkia biglobosa (10.09\%), and Ricinodendron heudelotii (8.62\%) were species with high importance in the floristic composition of Lugbe (Tables 2 and 3).

5.2. Benefits Derived from Urban Forests. Urban forest benefits are numerous, important, and beneficial to human livelihood, reduce health related problems, and contribute to the amelioration of both micro- and macroclimates. Table 4 indicates that people are aware of the various benefits derived from urban forest. The majority of respondents (70\%) in Lugbe (periurban area) and Abuja (urban area) opined that they derive fresh air from trees around them. A much higher percentage (85\%) of respondents in the periurban area derived fuelwood for their cooking purposes from urban forest when compared to the $10 \%$ of respondents in urban area who indicated that they sourced fuelwood from urban forests. About $50 \%$ and $65 \%$ of the respondents in urban and periurban centres, respectively, derived edible fruits from trees around them. Between 40 and $50 \%$ of the respondents in urban and periurban centres of the FCT indicated that they derived vegetables from trees around them, which they used for their diet. High percentage (60 to $75 \%$ ) of respondents in both urban and periurban centres use tree as windbreak to protect their buildings and other structures. The percentage of respondents who use trees for shade for the purpose of social gathering in both urban (Abuja; 60\%) and periurban areas (Lugbe; $75 \%$ ) is relatively high, which is similar to the percentage of those who use urban forest facilities for relaxation/garden/bar/joint purposes (70 to 60\%) (Table 4). About $40 \%$ and $50 \%$ of the respondents in Abuja city and Lugbe, respectively, make use of different parts of trees around them for medicines for curing different diseases (Table 4).

\section{Relationship between Tree Growth Variables}

Generally, there was positive and significant linear relationship between tree growth variables in both urban (Abuja city) and periurban (Lugbe) areas of the FCT (Tables 5 and 6). The correlation coefficient ranged from 0.16 to 0.96 in the periurban area (Lugbe) and from 0.26 to 0.97 in the urban area (Abuja city). The highest correlation coefficient was obtained between logarithmic transformed basal area and logarithmic transformed volume for trees in Lugbe (periurban area), while it was between height and basal area as well between logarithmic transformed basal area and logarithmic transformed volume for trees in Abuja city (urban area). Very weak correlation was observed between height and basal area $(0.16)$, height and diameter $(0.18,0.26)$, and diameter and basal area (0.29) for urban and periurban centres in the FCT.

\section{Results of Thematic Map Production and Green Area Index of Federal Capital Territory}

The thematic maps of the Federal Capita Territory (FCT) were produced from its satellite imagery using ArcGIS 10.3, which led to the generation of Normalized Difference Vegetation Index of the city for the years 2000 and 2015 (Figures 1(a) and 1(b)). Apart from the boundary of each FCT, the locations visited for data collected and NDVI were shown in the maps. The boundary was digitized to determine the size of the FCT, which was georeferenced with the attribute data collected from the field. The maps produced in this research reflected the level of flexibility of GIS in creating, calculating, 
TABLE 2: Biodiversity indices and growth parameters of individual trees in the urban areas (Abuja city) of the Federal Capital Territory, Nigeria.

\begin{tabular}{|c|c|c|c|c|c|c|c|c|c|c|}
\hline $\mathrm{S} / \mathrm{N}$ & Tree species & Family & FQ & MHt & MDbh & B.A & Vol. & $\mathrm{RD}$ & $\mathrm{RD}_{\mathrm{O}}$ & IVI \\
\hline 1 & Adansonia digitata & Bombacaceae & 3 & 4.2 & 51.0 & 1.84 & 7.72 & 0.43 & 3.60 & 2.02 \\
\hline 2 & Albizia falcata & Fabaceae & 1 & 19.8 & 16.0 & 0.02 & 0.40 & 0.14 & 0.04 & 0.09 \\
\hline 3 & Albizia ferruginea & Fabaceae & 1 & 17.0 & 138.0 & 1.50 & 25.43 & 0.14 & 2.93 & 1.54 \\
\hline 4 & Alstonia boonei & Apocynaceae & 1 & 14.6 & 86.4 & 0.59 & 8.56 & 0.14 & 1.15 & 0.65 \\
\hline 5 & Anacardium occidentale & Anacardiaceae & 1 & 18.8 & 32.0 & 0.08 & 1.51 & 0.14 & 0.16 & 0.15 \\
\hline 6 & Anogeissus leiocarpa & Combretaceae & 2 & 17.1 & 84.1 & 2.22 & 37.96 & 0.29 & 4.35 & 2.32 \\
\hline 7 & Azadirachta indica & Meliaceae & 16 & 19.1 & 11.9 & 2.86 & 54.56 & 2.31 & 5.60 & 3.96 \\
\hline 8 & Bambusa vulgaris & Poaceae & 3 & 16.6 & 12.8 & 0.12 & 1.93 & 0.43 & 0.23 & 0.33 \\
\hline 9 & Bauhinia monandra & Fabaceae & 5 & 12.7 & 11.7 & 0.27 & 3.44 & 0.72 & 0.53 & 0.63 \\
\hline 10 & Bauhinia polyantha & Leguminosae & 1 & 18.5 & 105.0 & 0.87 & 16.02 & 0.14 & 1.70 & 0.92 \\
\hline 11 & Blighia sapida & Sapindaceae & 1 & 13.4 & 65.0 & 0.33 & 4.45 & 0.14 & 0.65 & 0.40 \\
\hline 12 & Bosqueia angolensis & Moraceae & 24 & 18.8 & 3.2 & 0.46 & 8.66 & 3.47 & 0.90 & 2.19 \\
\hline 13 & Caesalpinia pulcherrima & Fabaceae & 3 & 11.7 & 6.0 & 0.03 & 0.30 & 0.43 & 0.05 & 0.24 \\
\hline 14 & Calliandra calothyrsus & Leguminosae & 7 & 8.6 & 8.3 & 0.26 & 2.26 & 1.01 & 0.52 & 0.76 \\
\hline 15 & Callitris intratropica & Cupressaceae & 1 & 16.8 & 112.0 & 0.99 & 16.55 & 0.14 & 1.93 & 1.04 \\
\hline 16 & Cassia pleurocarpa & Caesalpiniaceae & 7 & 8.4 & 4.6 & 0.08 & 0.69 & 1.01 & 0.16 & 0.59 \\
\hline 17 & Casuarina equisetifolia & Casuarinaceae & 11 & 10.8 & 6.6 & 0.41 & 4.41 & 1.59 & 0.80 & 1.19 \\
\hline 18 & Ceiba pentandra & Bombacaceae & 6 & 9.5 & 21.6 & 1.31 & 12.48 & 0.87 & 2.57 & 1.72 \\
\hline 19 & Citrus aurantifolia & Rutaceae & 9 & 14.2 & 7.9 & 0.39 & 5.61 & 1.30 & 0.77 & 1.04 \\
\hline 20 & Cleistopholis patens & Annonaceae & 5 & 15.6 & 17.4 & 0.59 & 9.27 & 0.72 & 1.17 & 0.94 \\
\hline 21 & Cocos nucifera & Arecaceae & 11 & 8.4 & 5.3 & 0.26 & 2.22 & 1.59 & 0.52 & 1.05 \\
\hline 22 & Cola gigantean & Malvaceae & 1 & 15.8 & 109.0 & 0.93 & 14.75 & 0.14 & 1.83 & 0.99 \\
\hline 23 & Corymbia citriodora & Myrtaceae & 1 & 13.4 & 36.0 & 0.10 & 1.36 & 0.14 & 0.20 & 0.17 \\
\hline 24 & Dacryodes edulis & Burseraceae & 1 & 12.6 & 74.8 & 0.44 & 5.54 & 0.14 & 0.86 & 0.50 \\
\hline 25 & Daniellia oliveri & Leguminosae & 20 & 12.8 & 7.2 & 1.62 & 20.70 & 2.89 & 3.17 & 3.03 \\
\hline 26 & Delonix regia & Fabaceae & 37 & 14.2 & 1.2 & 0.17 & 2.38 & 5.35 & 0.33 & 2.84 \\
\hline 27 & Drypetis spp. & Nymphalidae & 4 & 15.0 & 23.1 & 0.67 & 10.06 & 0.58 & 1.31 & 0.95 \\
\hline 28 & Elaeis guineensis & Arecaceae & 1 & 14.2 & 47.8 & 0.18 & 2.55 & 0.14 & 0.35 & 0.25 \\
\hline 29 & Eucalyptus camaldulensis & Myrtaceae & 1 & 11.0 & 42.0 & 0.14 & 1.52 & 0.14 & 0.27 & 0.21 \\
\hline 30 & Eucalyptus citriodora & Myrtaceae & 32 & 17.6 & 4.3 & 1.46 & 25.65 & 4.62 & 2.86 & 3.74 \\
\hline 31 & Eucalyptus forrestiana & Myrtaceae & 10 & 11.0 & 4.2 & 0.14 & 1.50 & 1.45 & 0.27 & 0.86 \\
\hline 32 & Euphorbia dendroides & Euphorbiaceae & 1 & 8.0 & 52.0 & 0.21 & 1.70 & 0.14 & 0.42 & 0.28 \\
\hline 33 & Ficus goliath & Moraceae & 14 & 15.5 & 5.0 & 0.38 & 5.93 & 2.02 & 0.75 & 1.39 \\
\hline 34 & Gmelina arborea & Verbenaceae & 72 & 14.0 & 1.2 & 0.63 & 8.83 & 10.40 & 1.24 & 5.82 \\
\hline 35 & Hildegardia baterii & Malvaceae & 1 & 15.7 & 89.6 & 0.63 & 9.90 & 0.14 & 1.24 & 0.69 \\
\hline 36 & Hura crepitans & Euphorbiaceae & 8 & 11.6 & 10.8 & 0.58 & 6.74 & 1.16 & 1.14 & 1.15 \\
\hline 37 & Jatropha curcas & Euphorbiaceae & 1 & 4.0 & 16.0 & 0.02 & 0.08 & 0.14 & 0.04 & 0.09 \\
\hline 38 & Khaya senegalensis & Meliaceae & 32 & 17.6 & 4.3 & 1.46 & 25.65 & 4.62 & 2.86 & 3.74 \\
\hline 39 & Lophira alata & Ochnaceae & 1 & 15.2 & 115.0 & 1.04 & 15.79 & 0.14 & 2.04 & 1.09 \\
\hline 40 & Lophira procera & Ochnaceae & 3 & 12.3 & 15.4 & 0.17 & 2.07 & 0.43 & 0.33 & 0.38 \\
\hline 41 & Mangifera indica & Anacardiaceae & 20 & 11.1 & 2.1 & 0.13 & 1.48 & 2.89 & 0.26 & 1.58 \\
\hline 42 & Milicia excelsa & Moraceae & 2 & 19.6 & 57.5 & 1.04 & 20.36 & 0.29 & 2.04 & 1.16 \\
\hline 43 & Milicia regia & Moraceae & 1 & 14.4 & 90.1 & 0.64 & 9.18 & 0.14 & 1.25 & 0.70 \\
\hline 44 & Millettia thonningii & Fabaceae & 5 & 13.5 & 14.5 & 0.41 & 5.59 & 0.72 & 0.81 & 0.77 \\
\hline 45 & Morinda lucida & Rubiaceae & 1 & 14.8 & 68.8 & 0.37 & 5.50 & 0.14 & 0.73 & 0.44 \\
\hline 46 & Moringa oleifera & Moringaceae & 2 & 17.0 & 16.5 & 0.09 & 1.45 & 0.29 & 0.17 & 0.23 \\
\hline 47 & Nauclea diderrichii & Rubiaceae & 2 & 15.5 & 68.0 & 1.45 & 22.49 & 0.29 & 2.84 & 1.57 \\
\hline 48 & Nauclea latifolia & Rubiaceae & 2 & 14.3 & 96.1 & 2.90 & 41.45 & 0.29 & 5.68 & 2.99 \\
\hline 49 & Parkia biglobosa & Fabaceae & 26 & 16.3 & 4.5 & 1.09 & 17.80 & 3.76 & 2.14 & 2.95 \\
\hline 50 & Pueraria phaseoloides & Leguminosae & 1 & 13.5 & 132.0 & 1.37 & 18.48 & 0.14 & 2.68 & 1.41 \\
\hline
\end{tabular}


TABle 2: Continued.

\begin{tabular}{|c|c|c|c|c|c|c|c|c|c|c|}
\hline $\mathrm{S} / \mathrm{N}$ & Tree species & Family & FQ & MHt & MDbh & B.A & Vol. & $\mathrm{RD}$ & $\mathrm{RD}_{\mathrm{O}}$ & IVI \\
\hline 51 & Pinus caribaea & Pinaceae & 7 & 11.9 & 8.0 & 0.25 & 2.95 & 1.01 & 0.49 & 0.75 \\
\hline 52 & Pinus caribaea & Pinaceae & 6 & 7.1 & 14.7 & 0.61 & 4.36 & 0.87 & 1.20 & 1.04 \\
\hline 53 & Plumeria alba & Apocynaceae & 19 & 12.1 & 3.7 & 0.39 & 4.78 & 2.75 & 0.77 & 1.76 \\
\hline 54 & Polyalthia longifolia & Annonaceae & 31 & 13.2 & 2.5 & 0.48 & 6.32 & 4.48 & 0.94 & 2.71 \\
\hline 55 & Psidium guajava & Myrtaceae & 3 & 19.4 & 14.2 & 0.14 & 2.77 & 0.43 & 0.28 & 0.36 \\
\hline 56 & Ravenala madagascariensis & Strelitziaceae & 1 & 15.4 & 36.0 & 0.10 & 1.57 & 0.14 & 0.20 & 0.17 \\
\hline 57 & Ricinodendron heudelotii & Euphorbiaceae & 1 & 6.8 & 171.0 & 2.30 & 15.62 & 0.14 & 4.50 & 2.32 \\
\hline 58 & Roystonea dunlapiana & Arecaceae & 24 & 16.6 & 5.6 & 1.40 & 23.31 & 3.47 & 2.75 & 3.11 \\
\hline 59 & Roystonea regia & Arecaceae & 21 & 17.8 & 3.8 & 0.49 & 8.79 & 3.03 & 0.97 & 2.00 \\
\hline 60 & Senna siamea & Fabaceae & 6 & 21.2 & 14.8 & 0.62 & 13.13 & 0.87 & 1.21 & 1.04 \\
\hline 61 & Spathodea campanulata & Bignoniaceae & 1 & 22.2 & 212.3 & 3.54 & 78.60 & 0.14 & 6.94 & 3.54 \\
\hline 62 & Tectona grandis & Lamiaceae & 11 & 16.0 & 10.7 & 1.09 & 17.50 & 1.59 & 2.14 & 1.87 \\
\hline 63 & Terminalia catappa & Combretaceae & 37 & 7.9 & 0.7 & 0.05 & 0.37 & 5.35 & 0.09 & 2.72 \\
\hline 64 & Terminalia ivorensis & Combretaceae & 42 & 9.1 & 0.7 & 0.08 & 0.70 & 6.07 & 0.15 & 3.11 \\
\hline 65 & Terminalia macroptera & Combretaceae & 31 & 11.6 & 3.5 & 0.92 & 10.71 & 4.48 & 1.81 & 3.14 \\
\hline 66 & Terminalia superba & Combretaceae & 9 & 12.7 & 13.6 & 1.17 & 14.85 & 1.30 & 2.29 & 1.80 \\
\hline 67 & Treculia africana & Moraceae & 1 & 6.0 & 85.8 & 0.58 & 3.47 & 0.14 & 1.13 & 0.64 \\
\hline 68 & Vachellia nilotica & Fabaceae & 17 & 9.2 & 3.6 & 0.30 & 2.74 & 2.46 & 0.58 & 1.52 \\
\hline \multirow[t]{2}{*}{69} & Vitex doniana & Verbenaceae & 2 & 16.4 & 42.5 & 0.57 & 9.31 & 0.29 & 1.11 & 0.70 \\
\hline & & & 692 & & & 51.02 & 752.75 & & & \\
\hline
\end{tabular}

FQ: number of tree stems in the city, B.A.: basal area of trees in the city, Vol.: volume of trees in the city.

TABLE 3: Biodiversity indices and growth parameters of individual trees in the periurban areas (Abuja city) of the Federal Capital Territory, Nigeria.

\begin{tabular}{|c|c|c|c|c|c|c|c|c|c|c|}
\hline $\mathrm{S} / \mathrm{N}$ & Tree species & Family & FQ & MHt & MDbh & B.A & Vol. & $\mathrm{RD}$ & $\mathrm{RD}_{\mathrm{O}}$ & IVI \\
\hline 1 & Albizia falcate & Fabaceae & 1 & 19.8 & 16.0 & 0.02 & 0.40 & 0.47 & 0.15 & 0.31 \\
\hline 2 & Azadirachta indica & Meliaceae & 16 & 19.1 & 11.9 & 2.86 & 54.56 & 7.51 & 20.85 & 14.18 \\
\hline 3 & Cleistopholis patens & Annonaceae & 5 & 15.6 & 17.4 & 0.59 & 9.27 & 2.35 & 4.34 & 3.34 \\
\hline 4 & Cocos nucifera & Arecaceae & 11 & 8.4 & 5.3 & 0.26 & 2.22 & 5.16 & 1.93 & 3.55 \\
\hline 5 & Delonix regia & Fabaceae & 17 & 14.2 & 2.7 & 0.17 & 2.38 & 7.98 & 1.22 & 4.60 \\
\hline 6 & Elaeis guineensis & Arecaceae & 1 & 14.2 & 47.8 & 0.18 & 2.55 & 0.47 & 1.31 & 0.89 \\
\hline 7 & Euphorbia dendroides & Euphorbiaceae & 1 & 8.0 & 52.0 & 0.21 & 1.70 & 0.47 & 1.55 & 1.01 \\
\hline 8 & Ficus goliath & Moraceae & 4 & 15.5 & 17.5 & 0.38 & 5.93 & 1.88 & 2.79 & 2.34 \\
\hline 9 & Gmelina arborea & Verbenaceae & 72 & 14.0 & 1.2 & 0.63 & 8.83 & 33.80 & 4.60 & 19.20 \\
\hline 10 & Hildegardia baterii & Malvaceae & 1 & 15.7 & 89.6 & 0.63 & 9.90 & 0.47 & 4.60 & 2.54 \\
\hline 11 & Jatropha curcas & Euphorbiaceae & 1 & 4.0 & 16.0 & 0.02 & 0.08 & 0.47 & 0.15 & 0.31 \\
\hline 12 & Mangifera indica & Anacardiaceae & 20 & 11.1 & 2.1 & 0.13 & 1.48 & 9.39 & 0.97 & 5.18 \\
\hline 13 & Nauclea diderrichii & Rubiaceae & 2 & 15.5 & 68.0 & 1.45 & 22.49 & 0.94 & 10.59 & 5.76 \\
\hline 14 & Parkia biglobosa & Fabaceae & 26 & 16.3 & 4.5 & 1.09 & 17.80 & 12.21 & 7.97 & 10.09 \\
\hline 15 & Ravenala madagascariensis & Strelitziaceae & 1 & 15.4 & 36.0 & 0.10 & 1.57 & 0.47 & 0.74 & 0.61 \\
\hline 16 & Ricinodendron heudelotii & Euphorbiaceae & 1 & 6.8 & 171.0 & 2.30 & 15.62 & 0.47 & 16.77 & 8.62 \\
\hline 17 & Senna siamea & Fabaceae & 6 & 21.2 & 14.8 & 0.62 & 13.13 & 2.82 & 4.52 & 3.67 \\
\hline 18 & Terminalia superba & Combretaceae & 9 & 12.7 & 13.6 & 1.17 & 14.85 & 4.23 & 8.53 & 6.38 \\
\hline 19 & Treculia Africana & Moraceae & 1 & 6.0 & 85.8 & 0.58 & 3.47 & 0.47 & 4.22 & 2.35 \\
\hline \multirow[t]{2}{*}{20} & Vachellia nilotica & Fabaceae & 17 & 9.2 & 3.6 & 0.30 & 2.74 & 7.98 & 2.18 & 5.08 \\
\hline & & & 213 & & & 13.7 & 191.0 & & & \\
\hline
\end{tabular}

FQ: number of tree stems in the city, B.A.: basal area of trees in the city, Vol.: volume of trees in the city. 


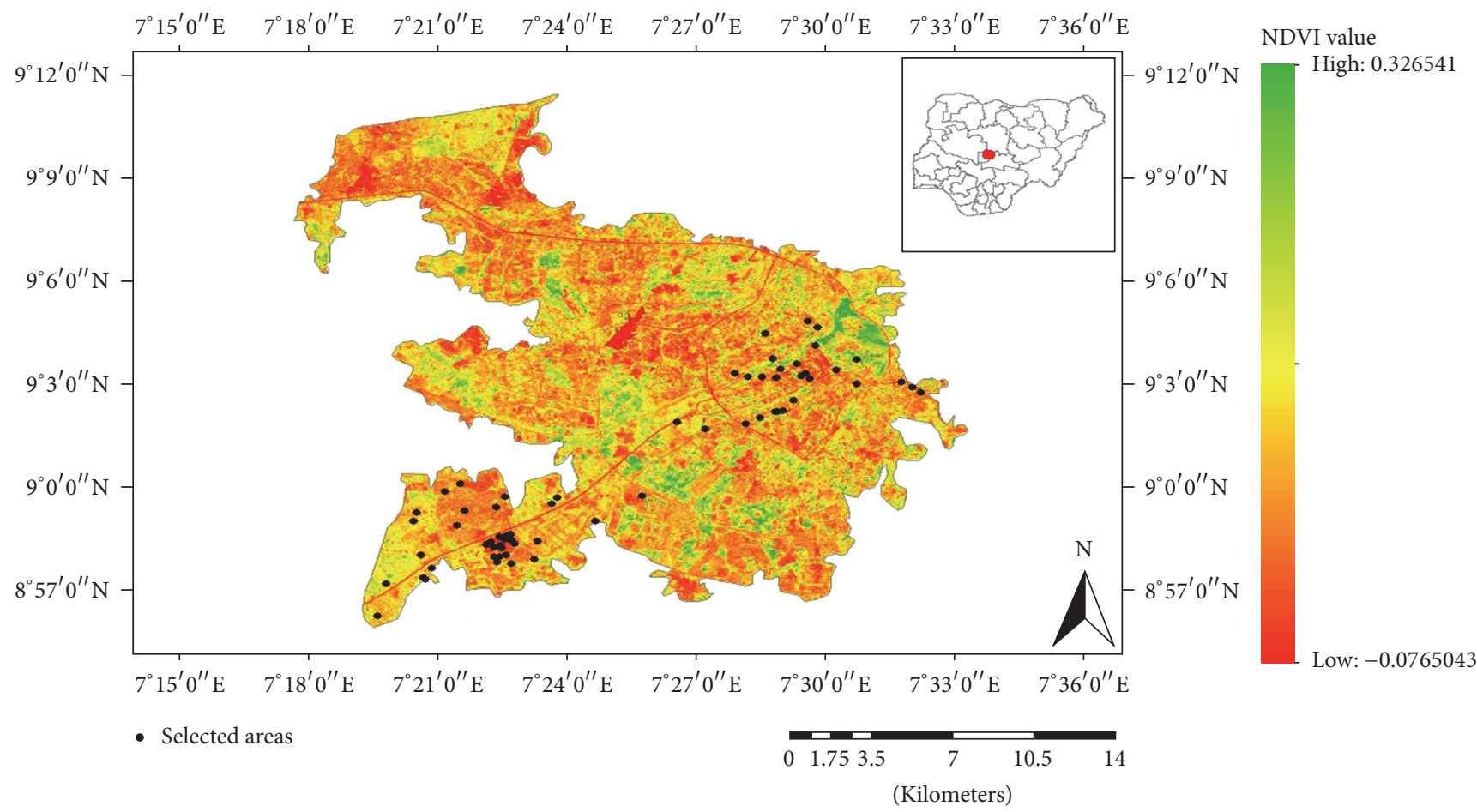

(a)

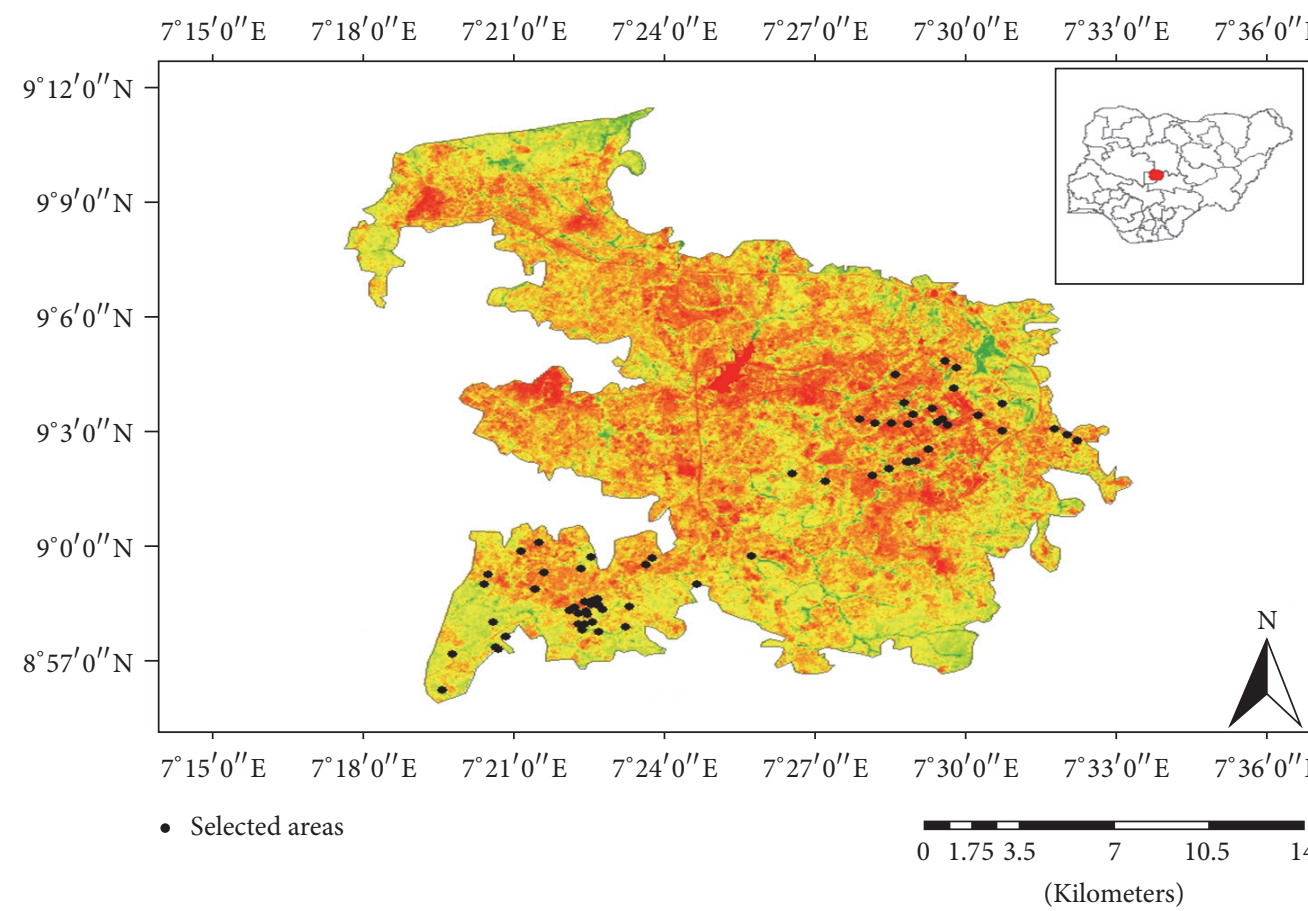

(b)

FIgURE 1: (a) Normalized Difference Vegetation Index (NDVI) map for Abuja for the year 2000 and sampling locations. (b) Normalized Difference Vegetation Index (NDVI) map for Abuja for the year 2015 and sampling locations.

and manipulating different research data for production of different maps. Normalized Difference Vegetation Index (NDVI) values of the city were calculated in ArcGIS 10.3 environment to determine the level of greenness of the city.
The NDVI value (0.327) for 2000 was relatively low but moderate. There was drastic reduction in the NDVI value (0.042) for 2015 which may be an indication of reduction and scattering in the vegetative cover of the FCT as a result 
TABLE 4: Benefits derived by respondents (\%) from urban and periurban forests in the Federal Capital Territory, Nigeria.

\begin{tabular}{lcc}
\hline \multirow{2}{*}{ Benefits derived } & \multicolumn{2}{c}{ Abuja (FCT) } \\
& Urban area (\%) & Periurban area $(\%)^{*}$ \\
\hline Medicine (herbs) & 40 & 50 \\
Relaxation/garden & 70 & 60 \\
Animal fodder & 15 & 50 \\
Fuel wood (cooking) & 10 & 85 \\
Shade (meetings) & 65 & 70 \\
Vegetable (soup) & 50 & 40 \\
Fresh air & 70 & 70 \\
Beautification & 90 & 50 \\
Edible fruits (food) & 50 & 65 \\
Windbreak & 60 & 75
\end{tabular}

${ }^{*}$ Respondents were allowed to choose more than one option (i.e., multiple responses).

of infrastructural development and population increase. The low value of NDVI in year 2015 has greater effects on the Land Surface Temperature (LST) and climate change of the city. The lower the NDVI value, the higher the LST, which tend to expose the city to more higher temperature and the climate change on the populace. Increase in NDVI value and reduction in LST value will create conducive environment for increase in tree diversity and green space coverage.

\section{Discussion}

8.1. Biodiversity Indices and Tree Growth Yield Variables. Forest ecosystems are pivotal to the functioning and conserving of biosphere, as they are the origin of many plants and animals [27]. The urban forests include trees planted along streets, compounds, school gardens, parks, riverbanks, city cemeteries, city vacant lots, adjacent wood land, and anywhere else where trees grow in urban areas $[28,29]$. Urban forests are among the in situ conservation methods that are essential in protecting and conserving tree species for the greatest benefits of the society. The results of this study confirmed that urban forest is a repository of many indigenous tropical hardwood and exotic tree species in different families, judging by the tree species richness of Abuja city, which is similar to or higher than what has been reported in some natural forest ecosystems in Nigeria [30-33]. For example, [30,31] reported 31 and 51 trees species in tropical rainforest ecosystems of southwestern Nigeria. A total of 56, 55, and 54 tree species were found in Sapoba, Shasha, and Ala forest reserves in Nigeria, respectively $[32,33]$. Thus, the large numbers of tree species that are found in tropical forests $[30,31]$ could also be said to be characteristics of urban forest landscapes. This similarity of tree species richness of urban centres and natural forest ecosystems underscores the importance of urban forests in biodiversity conservation and thus is evidence that urban forests can be both reservoirs and contributor to global biodiversity conservation.
Biodiversity indices of urban and periurban forests are generated in order to appreciate the level of diversity and abundance of species in built-up environment. IIRS [34] noted that biodiversity indices are generated to bring the diversity and abundance of species in different habitats to similar scale for comparison and the higher the value, the greater the species richness.

Konijnenddijk et al. [35] had noted that the levels of biodiversity in urban and periurban areas are often surprisingly high even when compared with forest trees diversity. The Shannon-Wiener diversity and Evenness indices of this study are higher than the values of Parthasarathy [36] and Yang et al. [37]. In another study, Duran et al. [38] obtained Shannon-Wiener diversity index range of between 2.69 and 3.33 which is within the range of the values reported for urban and periurban areas of FCT in this study. The ShannonWiener diversity index of Abuja city (i.e., urban area) in the study is within the range of the values reported for some natural tropical forest ecosystems $[30,31,33]$ as well as the values obtained by Agbelade et al. [11] for urban forests in Ibadan, southwestern Nigeria. However, the ShannonWiener diversity index of Lugbe (i.e., periurban area) is lower than the values reported by the studies mentioned above. The implication of this is that urban centres have higher species diversity than periurban areas, which is further confirmed by the higher species richness in Abuja city (urban area) compared to that of Lugbe (periurban area).

Though Alvey [39] reported that, traditionally, urban forest areas have been regarded as locations of low biodiversity that are dominated by nonnative species; evidence from this study as well as those from published information is mounting that urban and suburban areas can contain relatively high levels of biodiversity [40-42]. Contrary to the conclusion of Alvey [39], there are indications from the results of this study that urban and periurban forests have good store of both native and nonnative species. However, a higher percentage of the very common species are exotic species. Our results showed that Azadirachta indica, Eucalyptus species, Acacia species, and Gmelina arborea are the four most common species in Abuja, which is in agreement with the earlier study of Fuwape and Onyekwelu [2]. Three of these four most common species are exotic species. The tree planting and landscaping mechanism in Abuja may be responsible for the high level of tree species diversity encountered in it. The infrastructural development in Abuja city had low impact on the level of tree species diversity, which could be attributed to the careful planning, managing, and planting of trees. Thus it could be concluded that infrastructural development in Abuja city did not negatively affect the extent of biodiversity in it. This could imply that landscaping of the city was considered alongside with the infrastructural development. The spatial arrangement of trees as well as the choice and combination of tree species clearly distinguishes Abuja as a well-landscaped city. Nowak and Walton [43] noted that expanding urbanization increases the importance of urban forests in terms of their extent and the critical ecosystem services they provide to sustain human health and environmental quality in and around urban areas. In Guangzhou city, China, Jim and Liu [44] found over 250 plant species 
TABLE 5: Correlation coefficients for tree growth variables in periurban area (Lugbe).

\begin{tabular}{|c|c|c|c|c|c|c|}
\hline & Height & Diameter & Basal area (BA) & Volume (Vol.) & Ln BA & Ln Vol. \\
\hline Height & 1.00 & & & & & \\
\hline Diameter & .18 & 1.00 & & & & \\
\hline Basal area (BA) & .16 & .96 & 1.00 & & & \\
\hline Volume (Vol.) & .41 & .86 & .90 & 1.00 & & \\
\hline Ln BA & .17 & .93 & .81 & .71 & 1.00 & \\
\hline Ln Vol. & .44 & .88 & .76 & .74 & .96 & 1.00 \\
\hline
\end{tabular}

TABLE 6: Correlation coefficients for tree growth variables in urban area (FCT, Abuja).

\begin{tabular}{lccccc}
\hline & Height & Diameter & Basal area (BA) & Volume (Vol.) & Ln BA \\
\hline Height & 1.00 & & & & \\
Diameter & .26 & 1.00 & & & \\
Basal area (BA) & .97 & .26 & 1.00 & 1.00 & .73 \\
Volume (Vol.) & .87 & .47 & .93 & .83 & .00 \\
Ln BA & .94 & .25 & .80 & .76 & .96 \\
Ln Vol. & .91 & .49 & & & \\
\hline
\end{tabular}

after surveying over 115,000 plants in the parks on university grounds and along streets. This affirmed that there are relatively high numbers of stems found in urban centre, which could be higher than the number in conservation centres. Araújo [45] also asserted that human actions directly or indirectly increase the total number of species through introduced species and increase in landscape heterogeneity.

8.2. Benefits Derived from Urban and Periurban Forests. Tree species encountered in urban and periurban centres of the Federal Capital Territory, Abuja, are used for food (e.g., edible fruits/seeds, vegetables), nutrition supplement, medicinal substances, fuelwood, and animal fodder. Onyekwelu and Olaniyi [10] had observed that urban forestry practices improve food security of poor urban inhabitants through collection of wild edible plants as vegetable, planting of lowcare fruit bearing trees, including a gardening component, in multifunctional parks, or creating edible public parks. There are environmental benefits derived from urban forest such as purification of air (fresh air) wind break, provision of shade, beautification, relaxation parks, and gardens. Fuelwood, animal fodder, and edible fruits are among urban forest products sold for income generation. The higher percentage of respondents who collected fuelwood and animal fodder in Lugbe (periurban centres) compared to Abuja city (urban centre) could be compared. This could be an indication that higher percentage of periurban residents is more interested in income generation from urban forests. Income generation from urban and periurban forest products in Akure, Nigeria, ranged from $\$ 30$ to $\$ 150[10,46]$, which could further attest economic viability of urban forests in developing countries. Parks and recreation centres employ people as service men and women; thus the livelihood of these people depends on the income from these parks and recreation centres. Recreational centres differ from one another because of their relatively small size and type of use with relative amount of income generation for the people and government [10]. Recreation centres are suitable places for causal meetings, lunch outing, association meeting, family relaxation, business meetings, and holiday relaxation. Fuwape and Onyekwelu [2] observed that parks and recreation centres in cities across West Africa serve as small businesses centres, community meeting, religious worship centres, and shades for groves in some urban and periurban centres.

8.3. Green Index Mapping Using Normalized Difference Vegetation Index (NDVI). The low value of Normalized Difference Vegetation Index (NDVI) generated for Abuja proved that the vegetation coverage is scattered around the cities. In urban area, green spaces play important role in the quality of life and healthy nature of the ecosystem, which will improve the healthy nature of communities. The Federal Capital Territory (FCT) NDVI value indicated the presence of shrubs and scattered trees around the city. Xu et al. [47] and Miguel-Anyanz and Biging [48] opined that NDVI values of 0.1 to -0.1 represent degraded land; moderate values of 0.2 to 0.3 represent shrubs and grass land while 0.6 to 0.8 represent tropical forest land with vegetation coverage. Gillies and Carlson [49] reported that vegetation coverage has different impacts on recreation potential and microclimate of the environment, as well as improving the socioeconomic values of green spaces. Normalized Difference Vegetation Index (NDVI) is important parameter for the determinant of urban and periurban climate change and the Land Surface Temperature (LST), which relate the temperature generation and the cooling system of the vegetation coverage [50]. High level of tree species richness will enhance healthy vegetation coverage and reduces temperature of the atmosphere through evapotranspiration processes in green vegetation, which would be achieved if the high tree species 
richness in Abuja city is both maintained and improved. There is also need to substantially improve the vegetation cover of Lugbe, which is expected to contribute to reducing the usual high seasonal temperature. Miller [51] and Türk and Hastaoğlu [52] reported that areas where Land Surface Temperature (LST) is low, the Normalized Difference Vegetation Index (NDVI) values measurement are usually high which a sign of healthy vegetation coverage of the city. This can as well translate to healthy environment with healthy humans and other animals; it can also increase economic values of households.

\section{Conclusion and Recommendation}

The result of this research has provided baseline information on urban and periurban forests in the Federal Capital Territory (FCT) of Nigeria (Abuja), which can be used for the development of tree species database of the territory. The potentials of urban and periurban forests in conserving biodiversity and providing essential products and services towards environmental management, economic empowerment, and social services to the society were revealed. Different goods (edible fruits/seeds, vegetables, fuelwood, herbs, animal fodder, etc.) and services (parks, windbreak, pollution reduction, beautification, etc.) were provided by urban forests in the FCT. The sale of tree products provided much needed income, especially for periurban inhabitants.

This similarity of tree species richness of Abuja city (urban centre) and some natural forests confirms and underscores the importance of urban forests in biodiversity conservation; it is evidence that urban forests can be reservoirs and contributor to biodiversity conservation. The urban centre (Abuja city) had higher tree species richness and diversity than the periurban areas (Lugbe). The high species richness and diversity in Abuja city, despite its high infrastructural development, showed that infrastructural development in the city did not negatively affect its biodiversity conservation potential. The spatial arrangement of trees as well as the choice and combination of tree species shows that Abuja is a well-landscaped city. The maintenance and improvement of the high tree species richness and diversity in Abuja city will enhance healthy vegetation coverage and reduce temperature. There is need to substantially improve the vegetation cover of Lugbe in order to reduce its usually high seasonal temperature.

Forestry extension services should do more in educating the people on the benefits, importance, and contributions of urban forest to the environment and the people. It is important for government at all levels to be involved in planting trees in urban areas and create measures for the development of urban forests. Therefore, during the process of construction, expansion and infrastructure development attention should be paid to conserving trees rather than cutting them down.

\section{Competing Interests}

The authors declare that there is no conflict of interests regarding the publication of this paper.

\section{Acknowledgments}

This research was supported by the International Foundation for Science (IFS), Stockholm, Sweden, through a grant (D/5609-1) to Aladesanmi D. Agbelade. The authors also acknowledge International Institute of Tropical Agriculture (IITA), Ibadan, Nigeria, for scholarship in data processing and Normalized Difference Vegetation Index (NDVI) Map Production.

\section{References}

[1] D. J. Nowak and J. F. Dwyer, "Understanding the benefits and costs of urban forest ecosystems," in Urban and Community Forestry in the Northeast, J. E. Kuser, Ed., pp. 25-46, Springer, Dordrecht, The Netherlands, 2nd edition, 2007.

[2] J. A. Fuwape and J. C. Onyekwelu, "Urban forest development in West Africa: benefits and challenges," Journal of Biodiversity and Ecological Sciences, vol. 1, no. 1, pp. 77-94, 2011.

[3] UN-Habitat, State of African Cities; Re-Imagining Sustainable Urban Transitions, UN-Habitat Rapidly Expanding Regional Ststes of Cities Report Series, Design and Layout by Michael Jones Software (MJS), Nairobi, Kenya, 2014.

[4] United Nations, World Urbanization Prospects: The 2014 Revision, Department for Economic and Social Affairs, United Nations, New York, NY, USA, 2014.

[5] S. Angel, S. C. Sheppard, and D. L. Civco, The Dynamics of Global Urban Expansion, World Bank, Transport, Urban Development Department, Washington, DC, USA, 2011.

[6] M. Rajkumar and N. Parthasarathy, "Changes in forest composition and structure in three sites of tropical evergreen forest around Serigaltheri, Western Ghats," Current Science, vol. 53, pp. 389-393, 2008.

[7] K. C. Seto, A. Reenberg, C. G. Boone et al., "Urban land teleconnections and sustainability," Proceedings of the National Academy of Sciences, vol. 109, no. 20, pp. 7687-7692, 2012.

[8] P. O. Akunnaya and O. Adedapo, "Trends in urbanisation: implication for planning and low-income housing delivery in Lagos, Nigeria," Architecture Research, vol. 4, no. 1, pp. 15-26, 2014.

[9] J. F. Dwyer, D. J. Nowak, M. H. Noble, and S. M. Sisinni, "Connecting people with ecosystems in the 21st century: an assessment of our nation's urban forests," General Technical Report PNW-GTR-490, U.S. Department of Agriculture, Forest Service, PNRS, Portland, Ore, USA, 2000.

[10] J. C. Onyekwelu and D. B. Olaniyi, "Socio-economic importance of Urban and peri-urban forests in Nigeria," in Proceedings of the 6th Annual Conference of SAAT, FUTA, Adebayo, Ed., pp. 200210, Akure, Nigeria, November 2012.

[11] A. D. Agbelade, J. C. Onyekwelu, and O. Apogbona, "Assessment of Urban tree species population and diversity in Ibadan, Nigeria," Environmental and Ecology Research, vol. 4, no. 4, pp. 185-192, 2016.

[12] C. C. Konijnendijk, R. M. Ricard, A. Kenney, and T. B. Randrup, "Defining urban forestry-a comparative perspective of North America and Europe," Urban Forestry \& Urban Greening, vol. 4, no. 3-4, pp. 93-103, 2006.

[13] L. M. Westphal, "Urban greening and social benefits: a study of empowerment outcomes," Journal of Arboriculture, vol. 29, no. 3, pp. 137-147, 2003.

[14] O. Balogun, The Geography of Its Development, The Federal Capital Territory University Press, Ibadan, Nigeria, 2001. 
[15] P. E. Adakayi, “Climate," in Geography of Abuja, Federal Capital Territory, P. D. Dawam, Ed., Famous/Asanlu Publishers, Abuja, Nigeria, 2000.

[16] F. Ujoh, I. D. Kwabe, and O. O. Ifatimehin, "Understanding urban sprawl in the Federal Capital City, Abuja: towards sustainable urbanization in Nigeria," Journal of Geography and Regional Planning, vol. 3, no. 5, pp. 106-113, 2010.

[17] R. W. J. Keay, Trees of Nigeria, Oxford University Press, Oxford, UK, 1989.

[18] H. Liu and A. R. Huete, "A feedback based modification of the NDVI to minimize canopy background and atmospheric noise," IEEE Transactions on Geoscience and Remote Sensing, vol. 33, pp. 457-465, 1995.

[19] M. C. Imhoff, W. T. Lawrence, C. D. Elvidge et al., "Using nighttime DMSP/OLS images of city lights to estimate the impact of urban land use on soil resources in the United States," Remote Sensing of Environment, vol. 59, pp. 105-117, 1997.

[20] B. Husch, T. W. Beers, and J. A. Keenshaw Jr., Forest Mensuration, John Wiley \& Sons, Hoboken, NJ, USA, 4th edition, 2003.

[21] M. B. Brashears, M. A. Fajvan, and T. M. Schuler, "An assessment of canopy stratification and tree species diversity following clearcutting in central Appalachian hardwoods," Forest Science, vol. 50, no. 1, pp. 54-64, 2004.

[22] M. P. Aidar, J. R. Godoy, J. Bergmann, and C. A. Joly, "Atlantic Forest succession over calcareous soil, Parque Estadual Turístico do Alto Ribeira-PETAR, SP," Revista Brasileira de Botânica, vol. 24, no. 4, pp. 455-469, 2001.

[23] M. Kent and P. Coker, Vegetation Description and Analysis: A Practical Approach, John Wiley \& Sons, Chichester, UK, 1992.

[24] Y. Guo, P. Gong, and R. Amundson, "Pedodiversity in the United States of America," Geoderma, vol. 117, no. 1-2, pp. 99115, 2003.

[25] P. C. Nath, A. Arunachalam, M. L. Khan, K. Arunachalam, and A. R. Barbhuiya, "Vegetation analysis and tree population structure of tropical wet evergreen forests in and around Namdapha National Park, northeast India," Biodiversity and Conservation, vol. 14, no. 9, pp. 2109-2135, 2005.

[26] T. Sørenson, "A method of establishing groups of equal amplitude on similarity of species content," Biologiske Skrifter K. Danske Videnskbernes Selskab, vol. 5, no. 4, pp. 1-34, 1948.

[27] European Union, "Forest biodiversity as a challenge and opportunity for climate change adaptation and mitigation," in Informal Meeting of EU Environment Ministers, 12 pages, Ljubljana, Slovenia, April 2008.

[28] C. M. Shackleton, "Urban forestry-a Cinderella science in South Africa?” Southern African Forestry Journal, vol. 208, pp. $1-14$.

[29] J. C. Onyekwelu, "Urbanization and challenges of urban forestry. Green economy: balancing environmental sustainability and livelihoods in an emerging economy," in Proceedings of the 36thannual conference of the Forestry Association of Nigeria, Uyo, Akwa Ibom State, Popoola et al., Ed., pp. 402-419, November 2013.

[30] J. C. Onyekwelu, R. Mosandl, and B. Stimm, "Tree species diversity and soil status of primary and degraded tropical rainforest ecosystems in South-Western Nigeria," Journal of Tropical Forest Science, vol. 20, no. 3, pp. 193-204, 2008.

[31] D. L. Owen, "The glossary of forestry terminology," in South African Forestry Handbook 2000, D. L. Owen, Ed., pp. 724-734, SAIF, Pretoria, South Africa, 2000.
[32] R. G. Lowe, "Volume increment of natural moist tropical forest in Nigeria," Commonwealth Forestry Review, vol. 76, no. 2, pp. 109-113, 1997.

[33] V. A. J. Adekunle, "Conservation of tree species diversity in tropical rainforest ecosystem of southwest Nigeria," Journal of Tropical Forest Science, vol. 18, pp. 91-101, 2006.

[34] IIRS (Indian Institute of Remote Sensing), Biodiversity Characterization at Landscape Level in Western Ghats India Using Satelite Remote Sensing and GIS, Department of Space Dehradun, Indian Institute of Remote Sensing, National Remote Sensing Agency, Dehradun, India, 2002.

[35] C. Konijnenddijk, S. Sadio, T. Randrup, and J. Schipperijn, "Urban and peri-urban forestry in a development contextstrategy and implementation," Journal of Arboriculture, vol. 30, pp. 269-276, 2004.

[36] N. Parthasarathy, "Changes in forest composition and structure in three sites of tropical evergreen forest around Sengaltheri, Western Ghats," Current Science, vol. 80, no. 3, pp. 389-393, 2001.

[37] K.-C. Yang, J.-K. Lin, C.-F. Hsieh et al., "Vegetation pattern and woody species composition of a broad-leaved forest at the upstream basin of Nantzuhsienhsi in mid-southern Taiwan," Taiwania, vol. 53, no. 4, pp. 325-337, 2008.

[38] E. Duran, J. A. Meave, D. J. Lott, and G. Segura, "Structure and tree diversity patterns at landscape level in a Mexican tropical deciduous forest," Boletin De Sociedad Botanica De Mexico, vol. 79, pp. 43-60, 2006.

[39] A. A. Alvey, "Promoting and preserving biodiversity in the urban forest," Urban Forestry and Urban Greening, vol. 5, no. 4, pp. 195-201, 2006.

[40] A. Balmford, J. L. Moore, T. Brooks et al., "Conservation conflicts across Africa," Science, vol. 291, pp. 2616-2619, 2001.

[41] J. Cornelis and M. Hermy, "Biodiversity relationships in urban and suburban parks in Flanders," Landscape and Urban Planning, vol. 69, pp. 385-401, 2004.

[42] I. Kühn, R. Brandl, and S. Klotz, "The flora of German cities is naturally species rich," Evolutionary Ecology Research, vol. 6, pp. 749-764, 2004.

[43] D. J. Nowak and J. T. Walton, "Projected urban growth (20002050) and its estimated impact on the US forest resource," Journal of Forestry, vol. 103, pp. 383-389, 2005.

[44] C. Y. Jim and H. T. Liu, "Species diversity of three major urban forest types in Guangzhou City, China," Forest Ecology and Management, vol. 146, pp. 99-114, 2001.

[45] M. B. Araújo, "The coincidence of people and biodiversity in Europe," Global Ecology and Biogeography, vol. 12, pp. 5-12, 2003.

[46] J. C. Onyekwelu, "Biodiversity, socio-economic and cultural importance of trees in emerging Nigerian urban centres: case study of Akure city, Nigeria," in Proceedings of the 15th World Forestry Congress, Technical Paper, 8 pages, Durban, South Africa, September 2015.

[47] H. Xu, X. Wang, and G. Xiao, "A Remote Sensing and Gis Integrated Study On Urbanization with Its Impact On Arable Lands: Fuqing City, Fujian Province, China," Land Degradation \& Development, vol. 11, no. 4, pp. 301-314, 2000.

[48] J. S. Miguel-Anyanz and G. S. Biging, "Comparison of singlestage and multi-stage classification approaches for cover type mapping with TM and SPOT data," Remote Sensing of Environment, vol. 59, pp. 92-104, 1997. 
[49] R. R. Gillies and T. N. Carlson, "Thermal remote sensing of surface soil water content with partial vegetation cover for incorporation into climate models," Journal of Applied Meteorology, vol. 34, pp. 745-756, 1995.

[50] R. R. Gillies, T. N. Carlson, J. Cui, W. P. Kustas, and K. S. Humes, "A verification of the triangle method for obtaining surface soil water content and energy fluxes from remote measurements of the Normalized Difference Vegetation Index (NDVI) and surface radiant temperature," International Journal of Remote Sensing, vol. 18, pp. 3145-3166, 1997.

[51] R. W. Miller, Urban Forestry: Planning and Managing Urban Green Spaces, Prentice-Hall, Upper Saddle River, NJ, USA, 2nd edition, 1997.

[52] T. Türk and K. Hastaoğlu, "Mobile GIS application in urban areas and forest boundaries: a case study," in Proceeding of the 5th International Symposium on Mobile Mapping Technology, Padua University, Padua, Italy, May 2007. 

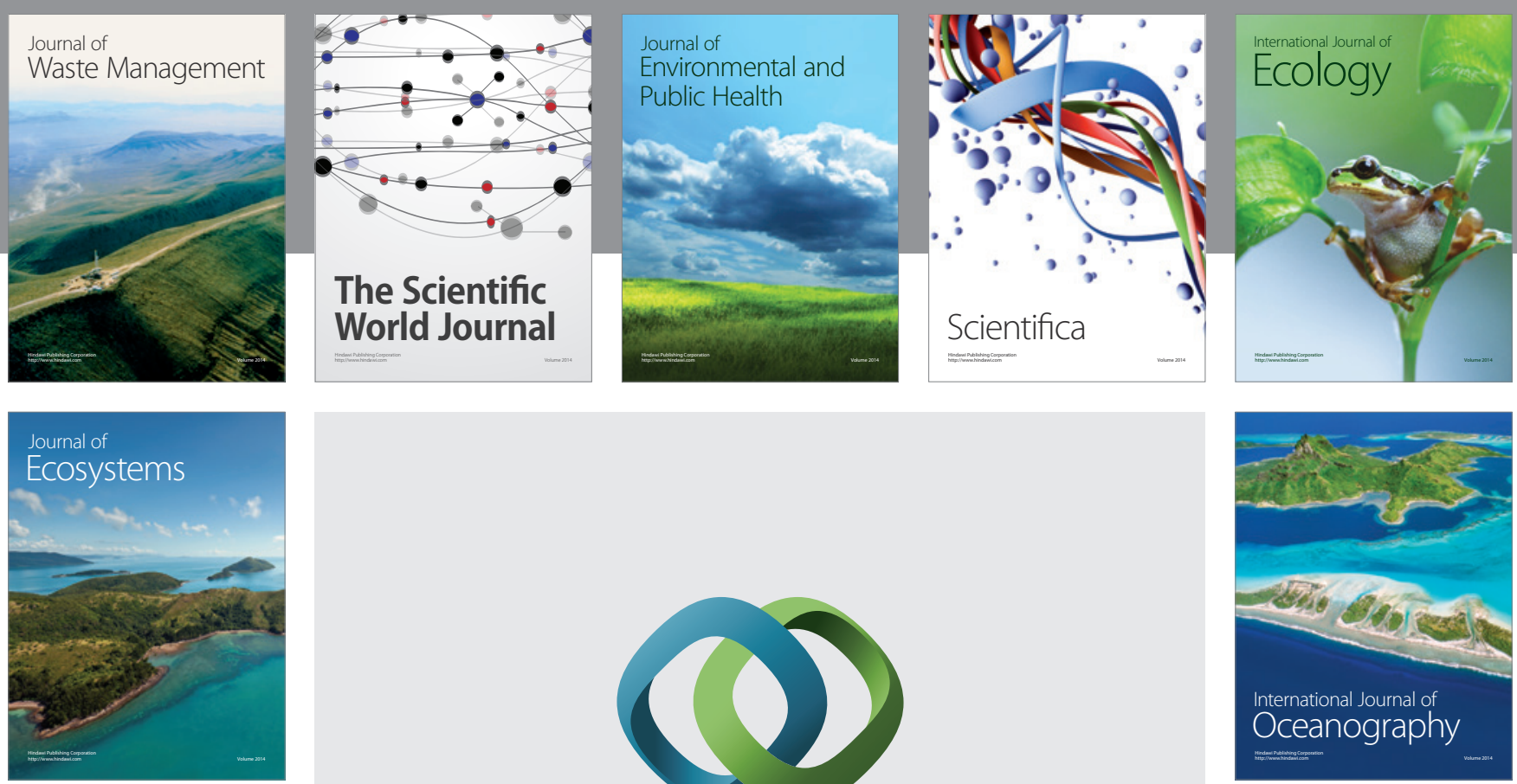

The Scientific World Journal
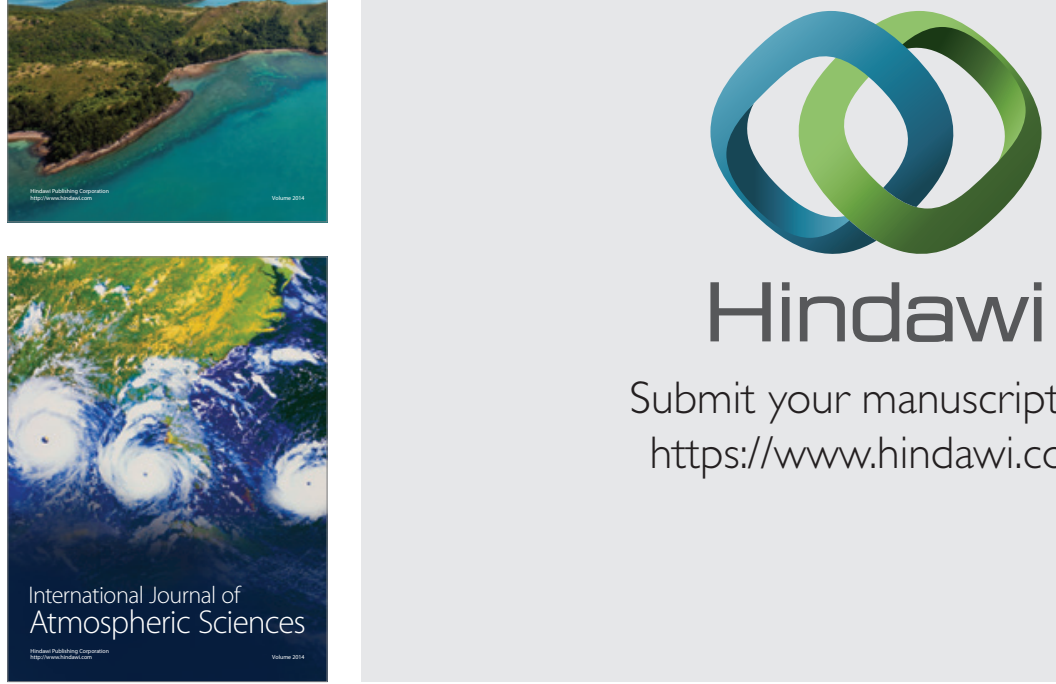

Submit your manuscripts at

https://www.hindawi.com
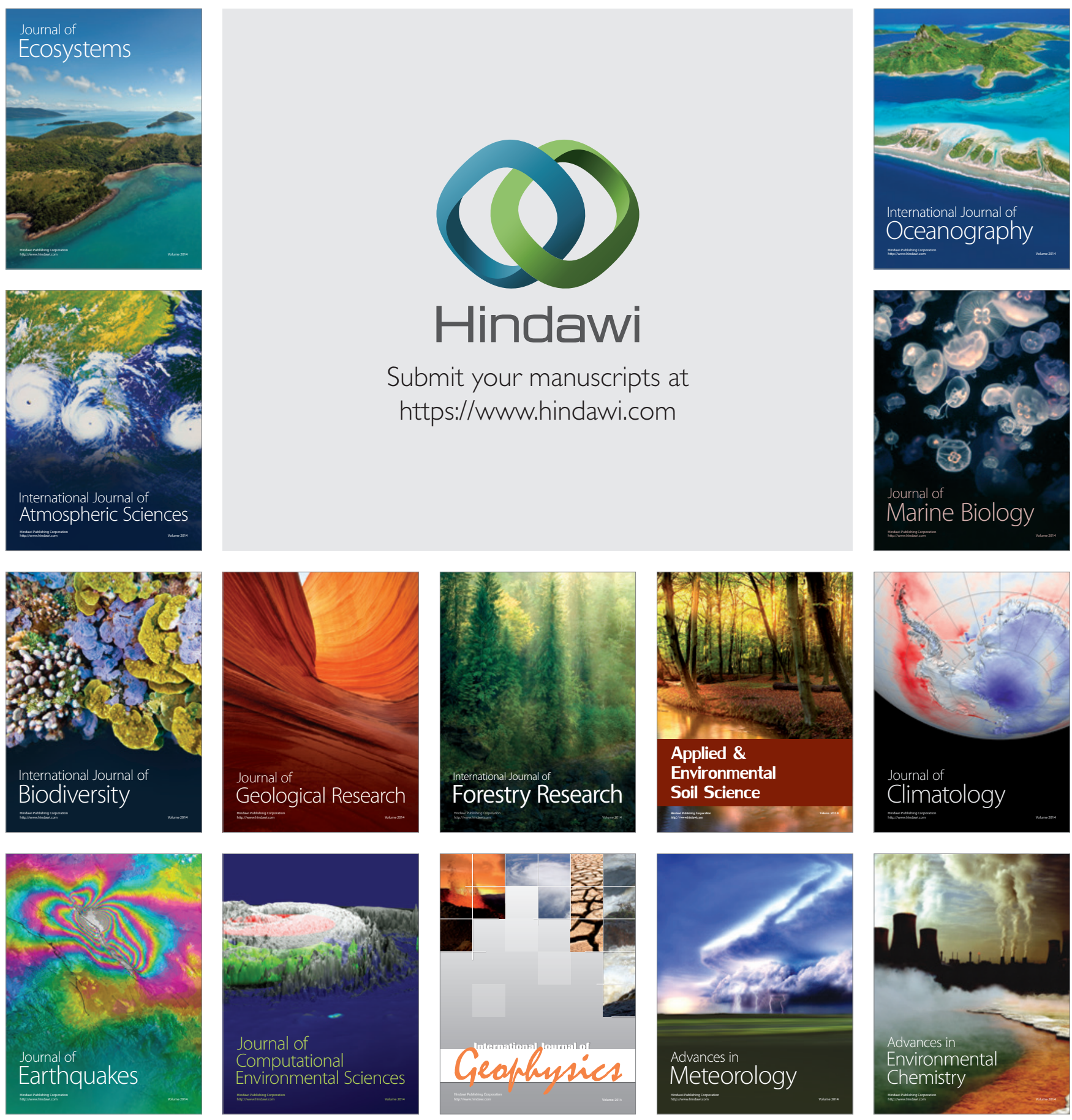